\title{
Prediction of Cumulative Installed Power of Geothermal Power Plants in Turkey by Using Artificial Neural Network and Bidirectional Long Short-Term Memory
}

\author{
Mehmet Hakan Özdemir ${ }^{1 *}$, Batin Latif Aylak ${ }^{2}$ \\ ${ }^{1^{*}}$ Turkish-German University, Faculty of Economic and Administrative Sciences, Departmant of Business Administration, İstanbul, Turkey, (ORCID: 0000-0002- \\ 7174-9807), hakan.ozdemir@tau.edu.tr \\ ${ }^{2}$ Turkish-German University, Faculty of Engineering, Departmant of Industrial Engineering, İstanbul, Turkey, (ORCID: 0000-0003-0067-1835), batin.latif@tau.edu.tr
}

(2nd International Conference on Applied Engineering and Natural Sciences ICAENS 2022, March 10-13, 2022)

(DOI: $10.31590 /$ ejosat.1080608)

ATIF/REFERENCE: Özdemir, M. H. \& Aylak, B. L. (2022). Prediction of Cumulative Installed Power of Geothermal Power Plants in Turkey by Using Artificial Neural Network and Bidirectional Long Short-Term Memory. European Journal of Science and Technology, (34), 280-284.

\begin{abstract}
Turkey has a great potential for renewable energies. The number of power plants (PP) producing electricity from renewable energy sources and accordingly the installed power has risen over the years. As of the end of December 2021, the cumulative installed power of Turkey reached 99819.6 MW and the share of the total installed power of the PPs generating electricity from renewable energy sources was $53.72 \%$. Although the installed power has increased, the percentage of PPs using renewable energy sources in total electricity generation is not yet at the desired level. However, geothermal energy is being used more and more in electricity generation alongside the other most well-known types of renewable energy. It can be observed that the installed power of geothermal power plants (GPP) in Turkey started to increase gradually after 2007, and as of the end of December 2021, the cumulative installed power reached 1676.2 MW. In this study, with the data for the cumulative installed power of GPPs in Turkey in the 2007-2021 period, the cumulative installed power of GPPs in Turkey for 2022 was predicted by using Artificial Neural Network (ANN) and Bidirectional Long ShortTerm Memory (BLSTM) methods, and the results were compared and interpreted.
\end{abstract}

Keywords: Installed power, Geothermal energy, Prediction, Artificial neural network.

\section{Türkiye'deki Jeotermal Enerji Santrallerinin Kümülatif Kurulu Gücünün Yapay Sinir A ̆ğ ve İki Yönlü Uzun-Kısa Vadeli Bellek Kullanılarak Tahmini}

$\ddot{O} \mathbf{z}$

Türkiye büyük bir yenilenebilir enerji potansiyeline sahiptir. Yenilenebilir enerji kaynaklarından elektrik üreten santrallerin sayısı ve buna bağlı olarak kurulu güç yıllar içinde artış göstermiştir. Aralık 2021 sonu itibarıyla Türkiye'nin kümülatif kurulu gücü 99819,6 MW'a ulaşmıştır ve yenilenebilir enerji kaynaklarından elektrik üreten enerji santrallerinin toplam kurulu güç içindeki pay1 \%53,72 olmuştur. Kurulu güç artmasına rağmen toplam elektrik üretiminde, yenilenebilir enerji kaynakları kullanan enerji santrallerinin oranı henüz istenen düzeyde değildir. Bununla birlikte, jeotermal enerji, en çok bilinen diğer yenilenebilir enerji türlerinin yanı sıra elektrik üretiminde giderek daha fazla kullanılmaktadır. Türkiye'de jeotermal enerji santrallerinin (JES) kurulu gücünün 2007 y1lından sonra yavaş yavaş artmaya başladığı ve Aralık 2021 sonunda kümülatif kurulu gücün 1676,2 MW'a ulaştı̆ğ görülmektedir. Bu çalışmada, Türkiye'deki JES'lerin 2007-2021 dönemindeki kümülatif kurulu gücü verileriyle, Yapay Sinir Ağı ve İki Yönlü Uzun-Kısa Vadeli Bellek kullanılarak Türkiye'deki JES'lerin 2022 yılı kümülatif kurulu gücü tahmin edilmiştir ve sonuçlar karşılaştırılarak yorumlanmıştır.

Anahtar Kelimeler: Kurulu güç, Jeotermal enerji, Tahmin, Yapay sinir ağı.

\footnotetext{
* Corresponding Author: hakan.ozdemir@tau.edu.tr
} 


\section{Introduction}

The rapidly increasing world population, industrialization and widespread use of electronic devices in daily life increase the demand for energy [1]. However, in order to make a certain quality of life sustainable, it is necessary to create a sustainable energy production system [2]. Although fossil energy sources, which are exhaustible and harmful to the environment, are still widely used today, the mentioned necessity has brought renewable energy sources to the agenda [3].

The installed power of PPs generating electricity from renewable energy sources in Turkey is increasing rapidly. According to the data by the end of December 2021, the total installed power of the PPs in Turkey is 99819.6 MW, and the total installed power of the PPs generating electricity from renewable energy sources is 53626.8 MW. Accordingly, the share of PPs generating electricity from renewable energy sources in the total installed power is $53.72 \%$. However, the share of electricity produced from fossil energy sources in total production is still very high. When the data for December 2021 are analyzed, it is seen that the share of PPs generating energy from renewable energy sources in electricity generation is $33.2 \%[4,5]$.

Geothermal energy is being used more and more in electricity generation alongside the other most well-known types of renewable energy. The number of GPPs has been increasing in recent years and as of the end of December 2021, the cumulative installed power of GPPs in Turkey has reached 1676.2 MW [5]. In Table 1, the cumulative installed power of GPPs in Turkey by years since 2007 is given.

Table 1. Cumulative installed power of GPPs in Turkey [5, 6]

\begin{tabular}{l|l}
\hline Year & $\begin{array}{l}\text { Cumulative installed power in } \\
\text { MW }\end{array}$ \\
\hline 2007 & 23.0 \\
\hline 2008 & 29.8 \\
\hline 2009 & 77.2 \\
\hline 2010 & 94.2 \\
\hline 2011 & 114.2 \\
\hline 2012 & 162.2 \\
\hline 2013 & 310.8 \\
\hline 2014 & 404.9 \\
\hline 2015 & 623.9 \\
\hline 2017 & 820.9 \\
\hline 2018 & 1063.7 \\
\hline 2019 & 1282.5 \\
\hline 2020 & 1514.7 \\
\hline 2021 & 1613.2 \\
\hline
\end{tabular}

In this study, with the data for the cumulative installed power of GPPs in Turkey in the 2007-2021 period, the cumulative installed power of GPPs in Turkey for 2022 was predicted by using ANN and BLSTM methods.

The rest of the study is structured as follows: A literature review is given in the second section. In the following section, the methods used in the study are explained. This is followed by the application in the fourth section, and the results are discussed in the fifth section. The conclusion is included in the sixth section.

\section{Literature Review}

The global issue of climate change and declining indigenous fossil fuels reserves have pushed the world to opt for renewable and clean energy resources. Geothermal energy is increasing its importance day by day. Various studies exist that made predictions related to geothermal energy. Shi et al. [7] effectively predicted the geothermal productivity using LSTM and MultiLayer Perceptron (MLP) combined ANN. In this, MLP was utilized to learn the nonlinear relationship between the constraint conditions and productivity of geothermal resource, whereas the LSTM system was utilized to memorize the sequential relation for the production data. They claimed their method was inexpensive as compared to numerical simulations. Moreover, they advocated that the combined model of LSTM and MLP provided better accuracy, generalization ability and stability, precision and forecasting efficiency as compared to original LSTM, MLP, Recurrent Neural Networks (RNN). The following claim was also supported by Gudmundsdottir and Horne [8]. They utilized standard feedforward neural network and RNN model for predicting geothermal reservoir through deep learning. Their study supported that feedforward neural network performed better than the complex RNN model and it should be implemented in prediction modeling for geothermal reservoirs. Similarly, Jiang et al. [9] also used RNN as Machine Learning (ML) architecture for the prediction of dynamic or sequential data in order to predict the long-term geothermal energy production. In addition to this, they utilized multiscale RNN to improve the generalization power (as simple RNN is challenged where extrapolation beyond the training range is needed) of the model and learning capability to predict both short-term and long-term trends in geothermal fields.

Diaz and Kim [10] opted ANN to predict and improve the rate of penetration (ROP) by training the system from data collected from an adjacent well in the geothermal project. They claimed that this method led to mean percentage error of $18.5 \%$. ROP was also predicted using ANN model for the nearby well in a geothermal field and this methodology was found to be quite accurate [11, 12]. Pérez-Zárate et al. [13] also utilized three-layer ANN to predict the geothermal reservoir temperatures and ultimately predict the potential energy extraction from that geothermal reservoir. They found out that the ANN model predicted the reservoir temperature with quite an accuracy with mean percentage error to be ranging from $2 \%$ to $11 \%$ between simulated and measured data. Similarly, Haklidir and Haklidir [14] also utilized ML approach to predict the reservoir temperature using hydrogeochemical data set for western Anatolia geothermal system in Turkey. Their study advocated that Deep Neural Network (DNN) showed the least root mean square error and mean absolute error and predicted the reservoir temperature most accurately. Contrary to the methodology utilized by Shi et al. [7], Jalilinasrabady et al. [15] used numerical simulation for assessing and predicting production for Takigami geothermal reservoir under two scenarios: $25 \mathrm{MW}$ and $36 \mathrm{MW}$ power production.

Coro and Trumpy [16] worked on predicting geographical feasibility of geothermal-based PPs through Maximum Entropy ML model. They claimed that their work would increase the transparency in the assessment of geothermal sites and help in saving time and money. Mao and Zhang [17] designed a transient temperature prediction model for analyzing the distribution of temperature in horizontal-wells during the drilling process for geothermal energy and shale gas. They modeled the transient 
temperature prediction system depending upon un-steady, twodimensional convection-diffusion equation and utilized finite volume method to solve the iteration model. Baruque et al. [18] developed a geothermal heat exchanger prediction model based on times series and optimization of monitoring sensors. In their study, they utilized statistical regression training tools (Ridge Regression ARIMA and Decision Tree) and ANN training tools (MLP, Time Delay Neural Network - TDNN). They found out that TDNN provided the best results in term of accuracy and predicted the state of installation up to $6 \mathrm{~h}$ in advance. Zhang et al. [19] designed a prediction model based on scaling deposition kinetics (utilizing Ramey model and inorganic scaling model) to accurately predict scale layer thickness and assess the blockage risk in the reinjection wellbore at different conditions.

\section{Methodology}

In this section, the methods used in the study will be briefly introduced.

\subsection{Artificial Neural Network (ANN)}

ANNs are a learning method that uses artificial intelligence and machines together to work exactly like nerve cells [20]. They usually contain the input layer, followed by single or more layers which are hidden, and then layer for the output, all of which are covered in neurons and weights. With this method, prediction and classification can be made with the aid of existing data. After training the system with real-life data, it may be possible to obtain outputs suitable for testing the complete system. There is a large number of application areas for ANNs, i. e. skin cancer level determination [21], detection of automobile engine faults [22], drug classification [23], electric load estimation [24], stock market forecast [25], wind speed estimation [26] and electricity energy demand forecasting [27].

\subsection{Bidirectional Long Short-Term Memory (BLSTM)}

ANNs give inspiration for several algorithms, including deep learning. Deep learning is used in many areas such as processing languages, processing images, and, classification work [28]. Its network differs from a classical ANN in many ways, for example, the number of layers [29]. The most popularly used algorithms for deep learning are CNN and RNN. A particular version of the regular RNN is Long Short-Term Memory (LSTM). One-way normal LSTMs tend to fail time series and other sequential operations as they are programmed for just one operation [30]. Bidirectional LSTMs run two LSTMs on the same input data in time series problems. The initial LSTM runs on the input data from backward to forward, and the next LSTM runs on the same data from forward to back [31]. In this way, by running two LSTMs on the same input data, the system is provided to be faster and the learning deficiencies in one-way LSTM are completed.

\section{Application and Results}

In this study, with the data in Table 1 for the cumulative installed power of GPPs in Turkey in the 2007-2021 period, the cumulative installed power of GPPs in Turkey for 2022 was predicted by using ANN and BLSTM methods. No Ethics Committee Permission is required because the data were gathered from the website of TEİAŞ (Turkish Electricity Transmission Corporation).
First, the data were converted into a series with three inputs and one output. Then ANN and BLSTM methods were applied.

For both ANN and BLSTM, the values of cumulative installed power of GPPs in Turkey from three successive years in Table 1 were used as input 1 (I1), input 2 (I2) and input 3 (I3). The value of cumulative installed power of GPPs in Turkey after these successive years was used as the only output $\mathrm{O}$ in Table 2. The I1, I2, I3 and $\mathrm{O}$ values in the first row of Table 2 are the cumulative installed power values of the GPPs in Turkey for the years 2007, 2008, 2009 and 2010, respectively. Those in second row are from the years 2008, 2009, 2010 and 2011. This is continued until the year 2021 .

Table 2. Data set values from cumulative installed power of GPPs in Turkey

\begin{tabular}{l|l|l|l}
\hline \multicolumn{1}{c|}{$\mathbf{I 1}$} & \multicolumn{1}{c|}{$\mathbf{I 2}$} & \multicolumn{1}{c|}{$\mathbf{I 3}$} & \multicolumn{1}{c}{ O } \\
\hline 23 & 29.8 & 77.2 & 94.2 \\
\hline 29.8 & 77.2 & 94.2 & 114.2 \\
\hline 77.2 & 94.2 & 114.2 & 162.2 \\
\hline 94.2 & 114.2 & 162.2 & 310.8 \\
\hline 114.2 & 162.2 & 310.8 & 404.9 \\
\hline 162.2 & 310.8 & 404.9 & 623.9 \\
\hline 310.8 & 404.9 & 623.9 & 820.9 \\
\hline 404.9 & 623.9 & 820.9 & 1063.7 \\
\hline 623.9 & 820.9 & 1063.7 & 1282.5 \\
\hline 820.9 & 1063.7 & 1282.5 & 1514.7 \\
\hline 1063.7 & 1282.5 & 1514.7 & 1613.2 \\
\hline 1282.5 & 1514.7 & 1613.2 & 1676.2 \\
\hline & & &
\end{tabular}

Different number of layers and neurons were tested in the training phase to obtain the best prediction with the ANN method. In order to form a network structure of 3-10-5-1, three inputs, one output and two hidden layers with 10 and 5 neurons respectively were used. Learning rate was adjusted as 0.5 and the sigmoid was used as activation function. The ANN training was executed with 200 epochs, and a value of 1642.8749608 was predicted for the actual value of 1676.2 in 2021 with a relative error of $-1.99 \%$.

Then BLSTM method was trained with 50 epochs. A value of 1672.2921 was predicted for the actual value of 1676.2 with a relative error of $-0.23 \%$.

Table 3. Predictions in MW for the value of cumulative installed power in 2021 (Two decimal places were used.)

\begin{tabular}{|c|c|c|c|c|}
\hline \multirow{2}{*}{$\begin{array}{l}2021 \\
\text { Actual } \\
\text { Value }\end{array}$} & \multicolumn{4}{|c|}{2021 Predictions } \\
\hline & ANN & $\begin{array}{c}\text { Relative } \\
\text { error }\end{array}$ & BLSTM & $\begin{array}{c}\text { Relative } \\
\text { error }\end{array}$ \\
\hline 1676.2 & 1642.87 & $-1.99 \%$ & 1672.29 & $-0.23 \%$ \\
\hline
\end{tabular}

Table 3 shows that BLSTM yields a better prediction than ANN. To predict the value of cumulative installed power in 2022 given in Table 4, ANN and BLSTM methods were applied with the training and optimization parameters obtained before. 
Table 4. Predictions in MW for the value of cumulative installed power in 2022

\begin{tabular}{c|c}
\hline \multicolumn{2}{c}{ 2022 Predictions } \\
\hline ANN & BLSTM \\
\hline 1705.69077345 & 1756.3717 \\
\hline
\end{tabular}

\section{Discussion}

In this study, with the data for the cumulative installed power of GPPs in Turkey in the 2007-2021 period, the cumulative installed power of GPPs in Turkey for 2022 was predicted by using ANN and BLSTM methods.

The cumulative installed power of GPPs in Turkey will increase by approximately 29.49 MW according to ANN method and by approximately $80.17 \mathrm{MW}$ according to BLSTM method in 2022.

\section{Conclusion}

Geothermal energy is a renewable, sustainable and inexhaustible type of energy. It is an important natural resource for Turkey. It is clean and environmentally friendly as it is not used in combustion technology and has close to zero emissions. Geothermal energy is also ideal for multipurpose heating applications. Therefore, it is used in housing, agriculture, industry and greenhouse heating. In addition, being independent of meteorological conditions makes it different from other renewable energy sources. It is a ready-made energy type and GPPs are base load PPs in electricity generation. It is cheaper than fossil and other alternative energy sources. It is also a reliable form of energy. There is no risk of explosion and poisoning in fire. Unlike hydro and solar energy, it requires minimal space. GPPs can be commissioned easily and quickly and have a long life span. Since geothermal energy is a domestic energy, it is not imported or exported and has no international price. Moreover, it does not cause international problems.

The importance of renewable energy is better understood with each passing day. Turkey has a great potential for renewable energies. The number PPs producing electricity from renewable energy sources and accordingly the installed power has increased over the years but the percentage of PPs using renewable energy sources in total electricity generation is not yet at the desired level. However, geothermal energy is being used more and more in electricity generation alongside the other most well-known types of renewable energy such as wind energy and solar energy. The results obtained in this study show that the installed power of geothermal power plants would increase in 2022, which gives rise to hope that the share of PPs using renewable energy sources in total electricity generation will increase in the future.

\section{References}

[1] K. Kaya, M. C. Şenel and E. Koç , "Dünyada ve Türkiye’de Yenilenebilir Enerji Kaynaklarının Değerlendirilmesi", Technological Applied Sciences, vol. 13, no. 3, pp. 219-234, Jul. 2018.

[2] Y. Akça and A. Kamacı, "TR81 Bölgesinin Yenilenebilir Enerji Durumu", Bartın Üniversitesi İktisadi ve İdari Bilimler Fakültesi Dergisi, vol 12, no. 24, pp. 400-412, 2021.

[3] D. G. Demir and M. Canbaz, "Türkiye'de 2001-2020 Yılları Arasında Devlet Teşviklerinin Yenilenebilir Enerji Sektörü
Üzerine Etkisinin Değerlendirilmesi: Türkiye'de 2001-2020 Yılları Arasında Devlet Teşviklerinin Yenilenebilir Enerji Sektörü Üzerine Etkisinin Değerlendirilmesi," Türk Kamu Yönetimi Dergisi, vol. 2, no. 2, 2021.

[4] C. Hakyemez (2022) Available: TSKB Ekonomik Araştırmalar Aylık Enerji Bülteni Aralık 2021. Available: https://www.tskb.com.tr/i/assets/document/pdf/enerjibulteni-aralik-2021.pdf.

[5] TEİAŞ (2021a). Aralık 2021 Kurulu güç raporu. Available: https://www.teias.gov.tr/tr-TR/kurulu-guc-raporlari.

[6] TEİAŞ (2021b). Türkiye'nin Yenilenebilir Kaynaklarına Ait Kurulu Gücünün Toplam Kurulu Güç İçindeki Payının Yıllar İtibariyle Gelişimi (2000-2020). Available: https://www.teias.gov.tr/tr-TR/turkiye-elektrik-uretimiletim-istatistikleri

[7] Y. Shi, X. Song, and G. Song, "Productivity prediction of a multilateral-well geothermal system based on a long shortterm memory and multi-layer perceptron combinational neural network," Applied Energy, vol. 282, p. 116046, Jan. 2021.

[8] H. Gudmundsdottir and R. N. Horne (2020, February). "Prediction modeling for geothermal reservoirs using deep learning" In 45th workshop on geothermal reservoir engineering. Stanford, California: Stanford University, 2020, pp. 1-12.

[9] A. Jiang, Z. Qin, T. T. Cladouhos, D. Faulder, and B. Jafarpour, "A Multiscale Recurrent Neural Network Model for Long-Term Prediction of Geothermal Energy Production", In 47th Workshop on Geothermal Reservoir Engineering Stanford University, Stanford, California, 2022, pp. 1-8.

[10]M. B. Diaz and K. Y. Kim, "Improving rate of penetration prediction by combining data from an adjacent well in a geothermal project," Renewable Energy, vol. 155, pp. 13941400, Aug. 2020.

[11]A. Yuswandari, A. Prayoga, and D. Purba, "Rate of penetration (ROP) prediction using artificial neural network to predict ROP for nearby well in a geothermal field," Proc. 44th Work. Geotherm. Reserv. Eng. Stanford Univ. Stanford, California, Febr. 11, vol. 13, no. 2019, pp. 1-5.

[12]M. Diaz, K. Y. Kim, J. Lee, and H.-S. Shin, "Prediction of rate of penetration with data from adjacent well using artificial neural network," in Geotechnics for Sustainable Infrastructure Development, Springer, 2020, pp. 517-522.

[13]D. Pérez-Zárate, E. Santoyo, A. Acevedo-Anicasio, L. DíazGonzález, and C. García-López, "Evaluation of artificial neural networks for the prediction of deep reservoir temperatures using the gas-phase composition of geothermal fluids," Computers \& Geosciences, vol. 129, pp. 49-68, 2019.

[14]F. S. Tut Haklidir and M. Haklidir, "Prediction of reservoir temperatures using hydrogeochemical data, Western Anatolia geothermal systems (Turkey): a machine learning approach," Natural Resources Research, vol. 29, no. 4, pp. 2333-2346, 2020.

[15]S. Jalilinasrabady, T. Tanaka, R. Itoi, and H. Goto, "Numerical simulation and production prediction assessment of Takigami geothermal reservoir," Energy, vol. 236, p. 121503, 2021.

[16]G. Coro and E. Trumpy, "Predicting geographical suitability of geothermal power plants," Journal of Cleaner Production, vol. 267, p. 121874, Sep. 2020. 
[17]L. Mao and Z. Zhang, "Transient temperature prediction model of horizontal wells during drilling shale gas and geothermal energy," Journal of Petroleum Science and Engineering, vol. 169, pp. 610-622, 2018.

[18]B. Baruque, S. Porras, E. Jove, and J. L. Calvo-Rolle, "Geothermal heat exchanger energy prediction based on time series and monitoring sensors optimization," Energy, vol. 171, pp. 49-60, 2019.

[19]L. Zhang, S. Geng, J. Chao, L. Yang, Z. Zhao, G. Qin, and S. Ren, "Scaling and blockage risk in geothermal reinjection wellbore: Experiment assessment and model prediction based on scaling deposition kinetics," Journal of Petroleum Science and Engineering, vol. 209, p. 109867, 2022.

[20]M. Hemmat Esfe, S. Saedodin, N. Sina, M. Afrand, and S. Rostami, "Designing an artificial neural network to predict thermal conductivity and dynamic viscosity of ferromagnetic nanofluid," International Communications in Heat and Mass Transfer, vol. 68, pp. 50-57, Nov. 2015.

[21] Ş. Öztürk and U. Özkaya, "Skin lesion segmentation with improved convolutional neural network." Journal of digital imaging, 33(4), 958-970, 2020.

[22]R. Ahmed, M. El Sayed, S. A. Gadsden, J. Tjong, and S. Habibi, "Automotive internal-combustion-engine fault detection and classification using artificial neural network techniques," IEEE Transactions on vehicular technology, vol. 64, no. 1, pp. 21-33, 2014.

[23]E. Byvatov, U. Fechner, J. Sadowski, and G. Schneider, "Comparison of support vector machine and artificial neural network systems for drug/nondrug classification," Journal of chemical information and computer sciences, vol. 43, no. 6, pp. 1882-1889, 2003.

[24]D. C. Park, M. A. El-Sharkawi, R. J. Marks, L. E. Atlas, and M. J. Damborg, "Electric load forecasting using an artificial neural network," IEEE transactions on Power Systems, vol. 6, no. 2, pp. 442-449, 1991.

[25]J. L. Ticknor, "A Bayesian regularized artificial neural network for stock market forecasting," Expert systems with applications, vol. 40, no. 14, pp. 5501-5506, 2013.

[26]A. Khosravi, R. N. N. Koury, L. Machado, and J. J. G. Pabon, "Prediction of wind speed and wind direction using artificial neural network, support vector regression and adaptive neuro-fuzzy inference system," Sustainable Energy Technologies and Assessments, vol. 25, pp. 146-160, 2018.

[27]S. Özden and A. Öztürk, "Yapay sinir ağları ve zaman serileri yöntemi ile bir endüstri alanının (ivedik OSB) elektrik enerjisi ihtiyaç tahmini," Bilişim Teknolojileri Dergisi, vol. 11, no. 3, pp. 255-261, 2018.

[28]L. Deng and D. Yu, "Deep learning: methods and applications," Foundations and trends in signal processing, vol. 7, no. 3-4, pp. 197-387, 2014.

[29]Y. LeCun, Y. Bengio, and G. Hinton, "Deep learning," nature, vol. 521, no. 7553, pp. 436-444, 2015.

[30]A. Graves and J. Schmidhuber, "Framewise phoneme classification with bidirectional LSTM and other neural network architectures," Neural networks, vol. 18, no. 5-6, pp. 602-610, 2005.

[31]E. Kiperwasser and Y. Goldberg, "Simple and accurate dependency parsing using bidirectional LSTM feature representations," Transactions of the Association for Computational Linguistics, vol. 4, pp. 313-327, 2016. 